\author{
English Language Teaching Educational Journal (ELTEJ) \\ Vol. 1, No. 2, 2018, pp. 97-105 \\ E-ISSN: 2621-6485
}

\title{
The Dynamicity of the Perceptive Verb Look: A Cognitive Linguistics Study
}

\author{
Prayudha, S.Pd., M.A. \\ Department of English Education, Universitas Ahmad Dahlan \\ prayudha@pbi.uad.ac.id
}

\begin{abstract}
Perceptive verbs have important function, especially in Cognitive Linguistics perspective, because these verbs are directly related to real experience. Cognitive linguistics focuses on the study of the relationship between language, mind, and socio-physical experience. Thus, this paper discusses how the lexical semantic characteristics particularly the dynamicity or aktionsarten of the verb look. The verb look itself consists agentive and perceptive verb class. The dynamicity of agentive and the perceptive verb look were analyzed using distributional method combined with several techniques. Most of the verb look constructions appear as phrasal verbs. At least, there are 17 phrasal verbs with look as the root and the constructions consist of at least 20 different meanings. The dynamicity test is also applicated for the phrasal verbs. The results of the research show unique lexical characteristics of the perceptive verb look and it influence the meaning as well as the construction of the verb. The relationship between lexical characteristic with its construction shows the schema of cognition processing language.
\end{abstract}

Keywords: Perceptive verbs; Cognitive linguistics, Dynamicity, Aktionsarten

How to Cite: Prayudha, P. (2018). The dynamicity of the perceptive verb look: A Cognitive Linguistics Study. English Language Teaching Educational Journal, 1(2), 97-105.

\section{INTRODUCTION}

Perceptive verbs are special, especially in cognitive linguistics. It is because cognitive linguistics focuses on the study of the relationship between language, mind, and socio-physical experience. Perceptive verbs have important function because these verbs are directly related to real experience. The verbs are the most basic verbs. Related to perceptive verb, Gisborne (2010: 181-182) says, "I claim that verbs of perception are special precisely because they are directly embodied and experiental... After all, we only become aware of motion and causation via perception, so in this sense, perception is even more basic". That is why perceptive is very beneficial to be analyzed. Thus, this paper discusses lexical semantic characteristics of verbs, particularly the dynamicity of the verb look.

Semantic features are related to the meaning and semantic properties of a verb lexically. The lexical characteristic is related to the dynamicity of a verb. Van Vallin (2005) says, "to be able to determine the structure of an argument from 
a verb, the first thing to do is to ascertain Actionsarten (the level of dynamism) of the verb" (p.59). This discussion is important to investigate the verb look. This is because the lexical semantic characteristics of the verb look will influence the structure of the argument.

A notable research which inspired the study is a research from Gisborne (2010) entitled The Event Structure of Perception Verbs. One of the discussions in the research is about dynamicity or Aktionsarten. According to Brinton (1988, in Gisborne, 2010), Aktiansarten is referred as actions which consist of: dynamism, telicity, and duration. Gisborne (2010) discuses dynamicity of perception verb in general. Some of his theories and approaches about perceptive verb are used in the research.

In order to find out how lexical semantic of the verb look, the step that must be done fist is to describe the definition of look. This definition will illustrate the lexical characteristics of the verb look. The definition is taken from the fourth edition of the Oxford Advanced Learner Dictionary. In the dictionary, the verb look has two definitions. The first definition is 'to turn one's eyes in a particular direction in order to see somebody or something.' The second definition of the verb look is 'to seem to be; to appear ' or 'looks like'. The verb look itself is a type of regular verb which is affixed \{-ed\} in the second and third form that is looked. From the definition above, look can be classified into several types. Levin (1993) classifies verbs which has the same characteristics with look as perceptive verbs: a verb related to stimulus.

\section{Cognitive Linguistics}

Cognitive linguistics is a relatively new study. The study that emerged in the late 1970s and began to develop in the 1980s tried to get out of the dominance of the formal approach in linguistic studies at that time. The birth of cognitive linguistics is influenced by the development of cognitive studies - regarding memory, perception, attention, and categorization - at that time especially cognitive psychology. Cognitive linguistics focuses on the study of the relationship between language, mind, and socio-physical experience. The relationship between the three according to Geeraerts and Cuyckens (2007) is that the formal structure of language is not learned autonomously, but rather a reflection on general conceptual organization through the categorization principles and processing mechanisms and the influence of experience as well as environment.

By that postulate, the definition of language becomes different in the cognitive linguistics perceptive. Lakoff (1990 in Evans, Bergan, \& Zinken, 2007) explains that cognitive linguistics has a number of key commitments. Evans \& Green (2006) divides the commitment into General Commitment and Cognitive Commitment. Both of them become determinants of theories and models of analysis in cognitive linguistic perspectives, including study of lexical semantic. Study of dynamicity of a verb becomes important and also reliable to conduct. 


\section{Perceptive Verb}

A verb is a class of words which usually functions as a predicate (Kridalaksana, 2008). Broadly speaking, Chafe (1970) distinguishes verbs into three types namely state verb, process verb, and action verb. State verb is a verb that states the condition of the subject. Process verb is a verb that explains a process of change experienced by the subject. Action verb is a verb describing what the subject does. The kind of verbs are divided to number of other types of verbs: action-process verb and experiential verb. Action-process verb is a verb that explains what the subject does while desiring the presence of another noun as an object. Meanwhile, the experiential verb is a verb that explain the things experienced by the nominee. Experimental verb itself is divided into emotional, cognitional, and perceptive verb. The perceptive verb is an experiential verb which the type of stimulus experienced by the subject is a sensation that can be received by the five senses (Jackendoff, 1976). Gisborne (2010) divides perceptive verb into three kinds: listen-class, hear-class, and sound-class.

\begin{tabular}{|l|l|l|}
\hline $\begin{array}{l}\text { Listen-class } \\
\text { (agentive) verbs }\end{array}$ & $\begin{array}{l}\text { Hear-class } \\
\text { (experiencer) verbs }\end{array}$ & $\begin{array}{l}\text { Sound-class } \\
\text { (percept) verbs }\end{array}$ \\
\hline Look/A & See & Look/P \\
Listen & Hear & Sound \\
Feel/A & Feel/E & Feel/P \\
Smell/A & Smell/E & Smell/P \\
Taste/A & Taste/E & Taste/P \\
\hline
\end{tabular}

\section{RESEARCH METHOD}

This descriptive qualitative research takes data from Oxford Dictionary and BNC (British National Corpus). At the collecting data process, sentences with different structure are selected from Oxford Dictionary. After that, the various structures where the verb "look" as head are taken from BNC. The organized data then were analyzed using distributional method. Distributional method is analytical method in linguistics that uses parts of the language itself as the determiner (Sudaryanto, 1993). There are some techniques in distributional method and the research used permutation technique, insertion technique, and deletion technique. The three different techniques were used because there are some steps in revivifying the aktionsarten of a verb.

\section{FINDINGS AND DISCUSSION \\ The Class of Verb Look}

From several types of perceptive verbs, look is divided into two types. Gisborne (2010) argues that the verb look consists agentive and perceptive verb class (referred as look [A]) and the pure perceptive verb classes (referred as look $[\mathrm{P}])$. The following data shows the differences between the two types of the perceptive verb look. 
(1) Elizabeth looked at her sister-in-law.

\section{(2) They look horrible!}

Data (1) shows the verb look [A] because it explains what the subject is experiencing. In Chafe (1970), the verb look [A] belongs to the experiential verb category. The verb look $[\mathrm{A}]$ is also referred to perceptual experience verbs that are directed at a stimulus or directed perception. The verbs which are classified as agentive perceptive verbs are check (on), gape, gawk, gaze, glance, glare, goggle, leer, listen (to), ogle, peek, peep, peer, sniff, snoop (on), squint, and stare. Data (1) is an agentive perceptive verb because it explains the things experienced by the subject, including the stimulus. It can be observed if the verb look at the data explains the stimulus her sister-in-law which are experienced by Elizabeth. The verb look $[\mathrm{A}]$ always requires a preposition when it appears in a construction. Both Levin (1993) and Gisborne (2010) concluded that look [A] collocated with preposition at.

Meanwhile, data (2) is a verb look [P] because the subject of the composition is equivalent to the object of look [A]. According to Chafe (1970), such verb falls into state verbs category because it explains the condition of the subject. More specifically, Jackendoff (1976) explains the verb falls into the category of static perceptive verbs or static perception verb. This verb type explains the condition of the stimulus. The stimulus is real or can be accepted by the five senses. Some of the verbs included in this type are feel, smell, sound, and taste. It can be observed if the subject they in the data (2) occupies the same role or equivalent to the object of her sister-in-law in the data (1) as something experienced or stimulus. The verb look in the data explains the condition of the stimulus.

\section{The Dynamicity of Agentive Verb look}

As an agentive perceptive verb, look [A] verb have their own semantic characteristics. This characteristic is related to the level of dynamics of the look verb $[\mathrm{A}]$. Dynamism of a verb is related to dynamism, telicity, and duration. To find out the dynamics of look [A] verbs can practice a number of tests. The following is data that shows dynamic look verbs $[\mathrm{A}]$.

(3) He looked at her with an icy contempt.

(3a) He \{was looking\} at her with an icy contempt.

(3b) He \{finished\} looking at her with an icy contempt.

(3c) He looks at her with an icy contempt \{for a minute\}. 
The data shows the lexical characteristics of verb look [A]. Data (3) shows the verbs look in an agentive perceptive class because the verb can answer a question about what is experienced by the subject as well as include the stimulus experienced. The verb look at the data explains the stimulus experienced by the subject he. Although the verb look [A] is a perceptive verb, this verb is dynamic because it is able to be present in a progressive period as indicated by data (3a). Regarding dynamism, Van Valin (2005) distinguishes perceptive verbs from dynamic verbs (activity verb) and static verbs (state verbs). Verb look [A] is a perceptive verb that is classified as an activity verb so that it is dynamic. In addition, look [A] verbs are included as telic verbs as shown in data (3b). It is because the data can be expanded by finished verbs which means stopping. Telis verbs are verbs that describe as completed actions (Kridalaksana, 2008). Data (3c) shows the verb look [A] is durative because it can be expanded with a description of time 'for a minute'. It means that the verb look [A] has a period of time when the action occurred. Durative verbs are verbs that show timeconsuming activities (Vendler, 1967 in Gisborne, 2010). It can be determined that the semantic characteristic of the verb look [A] is DYNAMIC, TELIC, and DURATIVE.

\section{The Dynamicity of The Perceptive Verb look}

The definition of the verb look $[\mathrm{P}]$ in the Oxford Advanced Learner's Dictionary shows that the verb is lexically different from the verb look [A]. Thus, the verb also has dynamic properties that are different from verb look [A]. It is as shown in the dynamic test of the verb look [P] as follows.

(4) That book looks interesting.

(4a) * That book \{is looking\} interesting.

(4b) * That book \{finished\} looking interesting.

(4c) *\{For an hour $\}$, that book looks interesting.

The test series in the data above shows the lexical properties of the verb look [P]. Data (4) shows the verb look in perceptive class because they cannot explain the activities carried out by the subject. The verb look at the data explains the state of the subject whose role as the stimulus. Data (4a) shows if the verb look $[\mathrm{P}]$ cannot appear in progressive times. Therefore, the verb look $[\mathrm{P}]$ can be said to be stative. Data (4b) cannot be expanded with information when it finished. It shows that the verb look $[\mathrm{P}]$ is not telic. On the contrary, the verb look $[\mathrm{P}]$ is atelic. Atelic verbs are verbs that describe actions that are not complete (Kridalaksana, 2008: 254). Data (4c) cannot be expanded with a time statement that explains the duration 'for one hour'. It shows if the verb look [P] is not durative but punctual. Punctual verbs are verbs that explain the situation right 
away. From the serial tests, it can be formulated that the semantic characteristic of verb look [P] is STATIC, ATELIC, and PANGTUAL.

\section{The Dynamicity of The Verb look in Phrasal Verb Construction}

There are many phrasal verb constructions in English. According to Jackendoff (2003), a phrasal verb consists of a verb as root which is paired with one or two particles. The term particle is used to make it easier to distinguish particles as prepositions in prepositional verbs and particles as adverb in the phrasal verb. Phrasal verb is almost exactly the same as the prepositional verb but both are different in treating particles. Phrasal verb treats particles as adverb while prepositional verb treats particle as preposition (Palmer, 1987). Phrasal verb orthographically separates the verb from its particle, but both are one unit and behave as a single verb. Biber, Johansson, Leech, Conrad, and Finegan (2007) explain that the phrasal verb is a multi-word unit consisting of a verb followed by adverb particles which indicate spatial meaning (directive) or aspect. The prepositional verb is the verb root look [A] that are collocated with a preposition at Levin (1993). In addition to the construction of verb + particle, similar construction can be classified as a horizontal verb. This includes the construction of look + particle at in its meaning extensions.

More verb look appears as in phrasal verb construction. According to Oxford Dictionary, at least, there are 17 phrasal verbs with look as the root. The phrasal verb are look after, look ahead, look at, look away, look back, look down, look for, look forward, look in, look into, look on, look out, look over, look around, look through, look to, and look up. The phrasal verbs have various meaning. There are 20 different meaning from the 17 phrasal verbs. It is because some phrasal verbs have more than one meaning. The different phrasal verbs meaning of course form differences of verb class. The condition lead to the diverse aktionsarten of the phrasal verb with look as the root. By using the same type of dynamism analysis for agentive verb look and perceptive verb look, here are the result of aktionsarten analysis of phrasal verbs with look as the root.

\begin{tabular}{|c|c|c|c|c|}
\hline No. & Meaning & $\begin{array}{l}\text { Phrasal } \\
\text { Verb }\end{array}$ & Verb Class & Aktionsarten \\
\hline 1. & to turn away & look away & $\begin{array}{l}\text { movement } \\
\text { verb }\end{array}$ & $\begin{array}{ll}\text { DYNAMIC, } & \text { TELIC, } \\
\text { DURATIVE } & \end{array}$ \\
\hline 2. & to stare & look on & $\begin{array}{l}\text { aspectual } \\
\text { verb }\end{array}$ & $\begin{array}{l}\text { DYNAMIC, } \\
\text { DURATIVE }\end{array}$ \\
\hline 3. & to think & look at & \multirow{4}{*}{$\begin{array}{l}\text { cognitive } \\
\text { verb }\end{array}$} & \multirow{4}{*}{$\begin{array}{l}\text { DYNAMIC, } \\
\text { DURATIVE }\end{array}$} \\
\hline \multirow[t]{2}{*}{4.} & \multirow[t]{2}{*}{ to predict } & look ahead & & \\
\hline & & look to & & \\
\hline 5. & to remember & look back & & \\
\hline \multirow[t]{2}{*}{6.} & \multirow[t]{2}{*}{ to consider } & look at & \multirow[t]{3}{*}{ emotive verb } & \multirow{3}{*}{$\begin{array}{l}\text { STATIC, } \\
\text { DURATIVE }\end{array}$} \\
\hline & & look on & & \\
\hline 7. & $\begin{array}{l}\text { to } \\
\text { underestimate }\end{array}$ & look down & & \\
\hline
\end{tabular}




\begin{tabular}{|c|c|c|c|c|}
\hline No. & Meaning & $\begin{array}{l}\text { Phrasal } \\
\text { Verb }\end{array}$ & Verb Class & Aktionsarten \\
\hline 8. & to admire & look up & & \\
\hline 9. & to feel happy & $\begin{array}{l}\text { look } \\
\text { forward }\end{array}$ & & \\
\hline 10. & to expect & look to & & \\
\hline 11. & to beware & look out & & \\
\hline 12. & $\begin{array}{l}\text { to become } \\
\text { better }\end{array}$ & look up & & \\
\hline \multirow[t]{2}{*}{13.} & to examine & look into & \multirow{15}{*}{$\begin{array}{l}\text { action- } \\
\text { process } \\
\text { verb }\end{array}$} & \multirow{15}{*}{$\begin{array}{l}\text { DYNAMIC, } \\
\text { DURATIVE }\end{array}$} \\
\hline & & look at & & \\
\hline 14. & to delve & $\begin{array}{l}\text { look } \\
\text { through }\end{array}$ & & \\
\hline \multirow[t]{3}{*}{15.} & \multirow[t]{3}{*}{ to search } & lookfor & & \\
\hline & & look out & & \\
\hline & & look up & & \\
\hline 16. & to share & look on & & \\
\hline \multirow[t]{2}{*}{17.} & \multirow[t]{2}{*}{ to take care of } & look after & & \\
\hline & & look out & & \\
\hline \multirow[t]{3}{*}{18.} & \multirow[t]{3}{*}{ to visit } & look over & & \\
\hline & & $\begin{array}{l}\text { look } \\
\text { around }\end{array}$ & & \\
\hline & & look up & & \\
\hline 19. & to avoid & look out & & \\
\hline \multirow[t]{2}{*}{20.} & \multirow[t]{2}{*}{ to read } & look over & & \\
\hline & & $\begin{array}{l}\text { look } \\
\text { through }\end{array}$ & & \\
\hline
\end{tabular}

In general, the phrasal verbs with look as root are at- least separated into movement verb, aspectual verb, cognitive verb, emotive verb, and action-process verb. A movement verb class, phrasal verbs with look as the root are DYNAMIC, TELIC, and DURATIVE. As aspectual verb, the phrasal verbs are DYNAMIC, TELIC, and DURATIVE. DYNAMIC, TELIC, and DURATIVE are also the semantic characteristic of cognitive phrasal verb. As an emotive verb class, phrasal verbs with look as the head are STATIC, ATELIC, and DURATIVE. The semantic characteristics of the action-process phrasal verbs DYNAMIC, TELIC, and DURATIVE.

\section{CONCLUSION}

Perceptive verbs are important to be analyzed because it directly embodied and experimental. Cognitively, the verbs are core class which will develop into other verb classes. The agentive verb look is dynamic, telic, durative. It synthetized that as agentive verbs, agentive verb look can be 
developed into various constructions. On the contrary, the perceptive verb look is static, atelic, and punctual. By the characteristic, the construction from the perceptive verb look is limited in intransitive construction. The result of the research can be developed into numerous hypotheses. Moreover, there are many verbs look in phrasal verb construction. At least, there are 17 phrasal verbs construction with look as the root with 20 meaning and 5 verb classes. The phrasal verbs consist of different meanings. If all of the constructions are analyzed, there will be unique network among them, and it shows how cognitive processing language works.

\section{REFERENCES}

Biber, Douglas., Johansson, Stig., Leech, Geoffrey., Conard, Susan., Finegan, Edward. (2007). Longman grammar of spoken and written English. London: Pearson Education Limited.

Chafe, Wallace L. (1970). Meaning and the structure of language. Chicago. University of Chicago Press.

Evans, Vyvyan. \& Green, Melanie. (2006). Cognitive linguistics: An Introduction. Edinburgh: Edinburgh University Press.

Evans, Vyvyan., Bergen, K. Benjamin, Zinken, Jörg. (2007). The cognitive linguistics reader. London: Equinox Publishing Ltd.

Geeraerts, D. \& Cuyckens, H. (2007). Introducing cognitive linguistics. In: Geeraerts, D. \& Cuyckens, H., The oxford handbook of cognitive linguistics. Oxford: Oxford University Press.

Gisborne, Nikolas. (2010). The event structure of perception verbs. New York: Oxford University Press.

Jackendoff, Ray. (2003). Foundations of language: Brain, Meaning, Grammar, Evolution. New York: Oxford University Press Inc.

Kridalaksana, Harimurti. (2008). Kamus linguistik. Jakarta: PT. Gramedia Pustaka Utama.

Levin, Beth. (1993). English verb classes and alternations: A Preliminary Investigation. Chicago: The University of Chicago Press, Ltd.

Palmer, Frank Robert. (1987). The English verb. Singapore: Longman Singapore Publisher, Ltd. 
Sudaryanto, (1993). Metode dan aneka teknik analisis bahasa. Yogyakarta: Duta Wacana University Press.

Van Valin, Robert D. JR. (2005). Exploring the syntax-semantics interface. New York: Cambridge University Press.

Online sourches:

Situs British National Corpus: http://www.natcorp.ox.ac.uk.

Situs etymonline: http://www.etymonline.com 